\title{
Histone H1.5
}

National Cancer Institute

\section{Source}

National Cancer Institute. Histone H1.5. NCI Thesaurus. Code C162851.

Histone $\mathrm{H} 1.5$ (226 aa, $\sim 23 \mathrm{kDa}$ ) is encoded by the human H1-5 gene. This protein is involved in linker histone activity. 